\title{
The Literature Review and Research Design of Pre-service English Teachers' Practical Knowledge about Lexical Teaching during the Teaching Practice ----A Case Study of Zhejiang Normal University
}

\author{
Bin Zhu, Yannan Xu \\ Zhejiang Normal University, Jinhua, Zhejiang, P. R. China \\ 912925506@qq.com
}

\begin{abstract}
Pre-service teacher education is the key procedure of student teacher's practical knowledge development. This paper first explores the strategies for developing pre-service English teachers' practical knowledge about lexical teaching,including imitation and innovation, learning in practice, communication, and reflection diary,based on cognitive learning theory and activity learning theory.The author then investigates the factors influencing the development of pre-service English teachers' practical knowledge about lexical teaching from the perspective of positive and negative. At last, this paper puts forward some suggestions to improve the development of pre-service English teachers' practical knowledge about lexical teaching all over China.
\end{abstract}

Index Terms - pre-service English teacher, teaching practice, practical knowledge, lexical teaching

\section{Introduction}

With the rapid development of the high school English curriculum reform, more and more experts of education have noticed the importance of the development of pre-service English teachers' practical knowledge. Pre-service English teachers' practical knowledge means the knowledge which pre-service English teachers accumulate and apply in the teaching practice. It consists of the knowledge of subject content, subject teaching, teachers' self-knowledge and curriculum knowledge. Pre-service English teachers' practical knowledge plays an extremely important role in the professional development of English teachers and the curriculum reform of English course in high school. Therefore, universities and colleges which are training English teachers for high school should pay more attention to the development of pre-service English teachers' practical knowledge.

Lexical teaching occupies an irreplaceable part in the English class in high school. It is an important as well as a difficult aspect in English teaching. Lexical teaching exists in different kinds of English classes such as language points, reading, listening, writing, homework explaining and so on. If an English teacher performs well in lexical teaching, it is natural that his students will get a better result in English tests and performs better in language use. Pre-service English teachers are senior English majors, they have gained a certain amount of English vocabulary, they know how to use the active words and how to understand the passive words in their own vocabulary. However, they lack the practical knowledge about lexical teaching which needs to be developed during teaching practice.

At present, few studies have been done about the development of pre-service English teachers' practical knowledge about lexical teaching. This study is to investigate the strategies for developing pre-service English teachers' practical knowledge about lexical teaching, and then analyze the influential factors in the development of pre-service English teachers' practical knowledge about lexical teaching. In this study, senior students majoring in English from Zhejiang Normal University who are going to have a teaching practice in high school are chosen as the participants. The data are obtained mainly from classroom observation, questionnaire and interview. With the first-hand collected data and discussion of the influential factors, implications will be proposed for improving the development of pre-service English teachers' practical knowledge about lexical teaching.

\section{Literature Review}

\section{A. Definition of pre-service English teachers' practical knowledge about lexical teaching}

The notion of pre-service English teachers' practical knowledge about lexical teaching is derived from teachers' practical knowledge. In order to have a clear definition about pre-service English teachers' practical knowledge about lexical teaching, we must first figure out the exact definition of teachers' practical knowledge. Teachers' practical knowledge has been interpreted differently in various studies at home and abroad. Elbaz argues that teachers' practical knowledge "encompasses first hand experience of students' learning style, interests, needs, strengths and difficulties, and a repertoire of instructional techniques and classroom management skills" (147-158). However, Clandinin regards teachers' practical knowledge as a kind of brief system. It is presented by conscious or unconscious in teachers' behaviors or their experience (1-34). Cheng Xiangming also claims that teachers' practical knowledge is the cognition of education and teaching which teachers truly believe in and apply or present in their teaching practice (106-112). Shen Jiliang's opinion about teachers' practical knowledge is that it is class contextual and other relevant knowledge (52-60).

As lexical teaching is an important aspect of English teaching, so in this paper, the author defines pre-service 
English teachers' practical knowledge about lexical teaching as an integrated cognitive system about lexical teaching which is developed gradually in teaching practice, truly believed and finally applied into new teaching context by pre-service English teachers.

\section{B. Related studies on pre-service English teachers' practical knowledge about lexical teaching}

In recent years, the topic of teachers' practical knowledge is becoming hotter and hotter in the field of teachers' education, and many studies related to teachers' practical knowledge have been done. According to Sun Guobin and Guo Jia's research, in recent 10 years, the research of teachers' practical knowledge in China mainly focus on the research of teachers' practical knowledge itself and the research of relations between teachers' practical knowledge and teacher development, and the latter is more(35-44). However, few studies related to pre-service English teachers' practical knowledge about lexical teaching have been done as it is too specific. Many studies have shown how teachers' practical knowledge guides their practice. Bullough presents a case study of how a teacher in America struggled to develop teaching skills in her first year and how she dealt with problems that is common to beginning teachers (5-90). Burns investigate the relationship between six English teachers' personalized theories and practices (56-66). He proves that raising teachers' conscious of the personalized theory can promote their practical ability (Burns 56-66). Fuller's study of the initiation of pre-service teachers enters into the profession through four stages of pre-service teachers' development: (1) Pre-service teachers start to get a grasp of their role as incipient eductors. (2) Pre-service teachers confront their teaching practice for the first time and strive for managing their classrooms. (3) Pre-service teachers transfer their learning to their teaching situations. (4) The new teachers need respond to the demands of their students (207-260). Wu Xin conducted a study about how 32 teachers became English teachers and how they succeeded in English teaching(121-129). In this study, those English teachers expressed their confusion about their own development when they were pre-service English teachers. Song Weihua believes that only through practice, experience, reflection and realization can pre-service teachers of foreign languages acquire practical knowledge, which will in turn promote their post-service professional development(78).

\section{Research Design}

\section{A. Research questions}

The objective of this research is to observe and find out the way of constructing pre-service English teachers' practical knowledge about lexical teaching. As the pre-service English teachers who have finished their teaching practice are the participants of this research, the author is trying to answer the following questions.

(1) What are the strategies for developing English teachers' practical knowledge about lexical teaching in pre-service period?
(2) What factors influence the development of pre-service English teachers' practical knowledge about lexical teaching at present?

(3) How to improve the current development of pre-service English teachers' practical knowledge about lexical teaching?

The main task of this research is to give constructional implications for improving the development of pre-service English teachers' practical knowledge about lexical teaching including improvement of the English teacher training curriculum, improvement of lexical teaching methods, improvement of English teachers' cognitive development, improvement of the evaluation of pre-service English teachers' practical knowledge about lexical teaching.

\section{B. Research subjects}

30 English majors of Zhejiang Normal University participated in this study. All of them shared similar English learning and teacher training background and had finished their teaching practice.

\section{Research Instruments}

\section{1) Classroom Observation}

As one of the 30 participants, the author observed these pre-service English teachers' teaching activity. Though these pre-service English teachers conducted their teaching practice in different high schools, but all of them wrote teaching diary and have at least one clip of teaching video. With these writing material and video clips, the author can get a clear idea of what is going on in English classes in high school and know the distance between college training curriculum and real high school English classes.

\section{2) Questionnaire}

The questionnaire was made aiming at investigating the present situation of English teacher training course related to pre-service English teachers' practical knowledge about lexical teaching in universities and colleges. The questionnaire was composed of satisfaction about the education of English lexical teaching and teacher training courses in Zhejiang Normal University which were presented in five-point Likert scale. In order to investigate the influential factors, open questions were designed to be answered. Some questionnaires were regarded as invalid as some participants did not complete the questionnaire as required.

\section{3) Interview}

Semi-open interview was organized with 20 subjects. The interview questions mainly focused on their teaching practice in high school. How do they acquire practical knowledge about lexical teaching and what difficulties they get into during their teaching practice was presented.

\section{Procedures}

This study was conducted half a year. As the focus of this study is pre-service English teachers' practical knowledge about lexical teaching, classroom observation must be carried out among pre-service English teachers when they were on their internship. The author was also one of those pre-service English teachers, so the authenticity of this study can be sure 
of. And more details about lexical teaching in high school will be observed and studied in this study. Meanwhile, more information about those pre-service English teachers' strategies of constructing practical knowledge about lexical teaching will be collected through talking with those pre-service English teachers, watching their teaching video and reading their reflecting diary related to lexical teaching.

The author also conducted questionnaire and interview so as to discover the influential factors related to the development of pre-service English teachers' practical knowledge about lexical teaching. The questionnaires were handed out aiming to investigate pre-service English teachers' satisfaction about their education related to English lexical learning and teaching and English teacher training in Zhejiang Normal University. The questionnaire was composed of options and open questions. The options were designed to indicate pre-service English teachers' possible reflection about the education in Zhejiang Normal University including "very satisfied", "satisfied", "basically satisfied", and "dissatisfied", "very dissatisfied". The open questions consisted of 6 terms about personal suggestions on the education in Zhejiang Normal University. The semi-open interview was carried out with the fixed subjects to discover the factors influencing the development of pre-service English teachers' practical knowledge about lexical teaching. The process of semi-open interview was note-taken with the participants' permission. All the data were compared carefully and the most common part was presented in the paper.

The data were collected mainly from the notes taken in the classroom observation, participants' answers to the questionnaires and the transcripts of semi-open interview. According to the data of classroom observation, the strategies for developing pre-service English teachers' practical knowledge about lexical teaching were analyzed and discussed in detail. The questionnaire and interview provided the data for studying the influential factors from the perspective of positive and negative, and then discussed these factors in the following parts.

\section{Conclusions}

The development of pre-service English teachers' practical knowledge about lexical teaching is difficult to observe, analyze and explain. Based on cognitive learning theory and activity learning theory, this paper aims to discover the strategies for developing pre-service English teachers' practical knowledge about lexical teaching and find out the factors influencing the development of pre-service English teachers' practical knowledge about lexical teaching.

Firstly, most pre-service English teachers use four strategies to develop their practical knowledge about lexical teaching. These four strategies are imitation and innovation, learning in practice, communication, and reflection diary.

Secondly,At last, this paper puts forward some methonds for improving the development of pre-service English teachers' practical knowledge about lexical teaching, including improvement of curriculum, improvement of teaching methods, and improvement of the assessment of practical knowledge about lexical teaching.

To conclude, pre-service English teachers should pay more attention to the development of their practical knowledge about lexical teaching. And normal universties in China should make effort to cultivate pre-service English teachers' practical knowledge about lexical teaching.

This study had some limitations that should be taken into consideration. Firstly, the samples only represent a small group of pre-service English teachers in Zhejiang Normal University. So the subjects cannot representing pre-service English teachers all over China. Secondly, those pre-service English teachers conducted their teaching practice in different schools, so their experience may be different. And this difference will influence the result of this study.

\section{References}

[1] Burns, A., "Teacher beliefs and their influence on classroom practice." Prospect, vol.7, pp. 56-66, 1992.

[2] Bruner, Jerome Seymour, Acts of meaning. Cambridge, Massachusetts: Harvard University Press, pp. 67-98, 1990.

[3] Bullough, Robert, V. First-year teacher: a case study. New York: Teachers College, Columbia University, pp. 5-90, 1989.

[4] Clandinin, D. Jean., Classroom practice: teacher images in action. London: Falmer Press, pp. 1-34, 1986.

[5] Elbaz, Freema, "The teacher's 'practical knowledge': report of a case study." Curriculum Inquiry. vol.11,pp. 43-71,1981

[6] Fuller, Frances F, "Concerns of teachers: a developmental conceptualization." American educational Research Journal. vol.6,pp. 207-260,1969

[7] Shulman, L.S, "Those who understand: Knowledge growth in teaching." Educational Researcher, vol.1,pp. 4-14,1986..

[8] Wu, Xin, Teacher Change: Issues in In-service EFL Teacher Education. 1st ed. Beijing: Beijing Jingke Press Company, pp. 121-129,2005

[9] Chen Xiangming, " Practical Knowledge: the Knowledge Base of Teachers' Professional Development". Peking University Education Review.vol.1, pp. 106-112, 2003.

[10]Guobin, Sun, and Guo Jia, "The Review of Teachers' Practical Knowledge of China in Recent 10 Years." .Journal of Qilu Normal University, vol.1,pp. 35-44,2012

[11]Shen Jiliang, The role reshaping of teachers in new century: the base of teachers' development. Beijing: Beijing Normal University Press, pp. 52-60, 2006. 